\title{
Penerapan Komunitas Belajar Melalui Aplikasi WhatsApp sebagai upaya Meningkatkan Aktivitas Belajar Sejarah
}

\author{
Rizal Arizaldy Ramly ${ }^{1}$ \\ Teknologi Pendidikan, Fakultas Keguruan dan Ilmu Pendidikan, Universitas Muhammadiyah \\ Makassar $^{1}$ \\ arizaldyramly@gmail.com ${ }^{1}$
}

\begin{abstract}
Abstrak
Penelitian ini mengandung unsur penerapan komunitas belajar melalui aplikasi whatsapp sebagai upaya meningkatkan aktivitas belajar sejarah dengan mengambil lokasi di SMA Muhammadiyah 1 Unismuh Makassar khususnya pada siswa kelas X. Dalam penelitian ini mengangkat permasalahan bagaimana penerapan aplikasi tersebut mempengaruhi aktivitas elajar sejarah siswa. Sementara itu tujuan penelitian disusun untuk meningkatkan untuk meningkatkan aktivitas belajar mata pelajaran sejarah dengan penerapan komunitas belajar melalui aplikasi whatsapp. Penelitian ini menggunakan pendekatan kuanlitatif dengan jenis deksriptif. Teknik pengumpulan data dengan melibatkan siswa dan guru sebagai responden melalui penyebaran angket dan wawancara. Selain dari itu, untuk teknik analisis data meliputi menyajikan data berdasarkan hasil wawancara serta angket dalam bentuk persentase dan rata-rata kemudian penarikan kesimpulan. Subjek penelitian siswa kelas X SMA Muhammadiyah 1 Unismuh makasssar sebanyak 22 siswa di dalam kelas dan 15 siswa yang tergabung di dalam komunitas whatsapp. Hasil penelitian menunjukan bahwa penerapan komunitas belajar melalui aplikasi whatsapp dapat meningkatkan aktivitas belajar siswa dapat dilihat dari hasil wawancara dengan guru dan siswa, serta dapat dilihat dari nilai rata-rata persentase pada siklus I dengan pernsentase aktivitas siswa adalah $48.63 \%$ dan siklus II dengan nilai persentase aktivitas siswa meningkat menjadi 55.29\%. Jadi dapat ditarik kesimpulan bahwa penerapan komunitas melalui aplikasi whatsapp dapat meningkatkan aktivitas belajar siswa kelas X pada mata pelajaran sejarah di SMA Muhammadiyah 1 Unismuh Makassar.
\end{abstract}

Kata Kunci: Komunitas Belajar; Whatsapp; Aktivitas Belajar.

\section{Abstract}

This research contains elements of implementing a learning community through the WhatsApp application as an effort to increase history learning activities by taking the location at SMA Muhammadiyah 1 Unismuh Makassar, especially for class $X$ students. This study raises the problem of how the application of the application affects students' history learning activities. Meanwhile, the purpose of the research is to improve the learning activities of history subjects by implementing a learning community through the WhatsApp application. This study uses a qualitative approach with descriptive type. Data collection techniques by involving students and teachers as respondents through the distribution of questionnaires and interviews. Apart from that, the data analysis technique includes presenting data based on the results of interviews and questionnaires in the form of percentages and averages then drawing conclusions. The research subjects were 22 students in class X SMA Muhammadiyah 1 Unismuh Makassar and 15 students who were members of the WhatsApp community. The results showed that the application of the learning community through the WhatsApp application could increase student learning activities, it can be seen from the results of interviews with teachers and students, and it can be seen from the average percentage value in the first cycle with the percentage of student activity being $48.63 \%$ and the second cycle with the percentage value. student activity increased to $55.29 \%$. So it can be concluded that the application of 
the community through the WhatsApp application can increase the learning activities of class $X$ students in history subjects at SMA Muhammadiyah 1 Unismuh Makassar.

Keywords: Learning Community; Whatsapp; Learning Activities.

Diterima (16 Agustus 2021) Disetujui (26 Agustus 2021) Dipublikasikan (29 September 2021)

\section{PENDAHULUAN}

Proses dalam pendidikan memberikan makna sebagai upaya untuk perbaikan dan peningkatan kualitas diri seseorang. Pendidikan memberikan dampak terhadap pertumbuhan dan perkembangan diri dan juga dengan orang lain. Hal ini tidak dapat terpisahkan dari sebuah bentuk perlakuan sosial secara interaktif dalam bermasyarakat. Proses interaksi ini akan menjadi sebuah sumbangan sebagai sumber daya manusia yang tidak terpisahkan oleh tujuan dan indikator pendidikan, selain itu nilai yang juga ikut adlah identitas budaya yang diyakini untuk dilaksanakan dalam kehidupan sosial. Pendidikan sangat memberikan pengaruh dalam proses kehidupan bermasyarakat, sehingga ini erat kaitannya dengan moral anak bangsa. Oleh sebab itu, perkembangan pendidikan ini menjadi tonggak dalam perubahan serta perkembangan suatu bangsa dan negara.

Saat ini perkembangan zaman telah berada pada era sains dan teknologi, artinya bahwa kehidupan social telah dipenuhi dengan pertumbuhan Teknologi Informasi dan Komunikasi (TIK) yang pesat. Seluruh lini kehidupan telah tersentuh dengan keberadaan teknologi yang serba canggih. Perkembangan teknologi sangat berdampak pada pendidikan yang dapat meningkatnya kemampuan intelektual, spiritual dan emosional/sikap pada masyarakat terkhusus pada generasi muda. Pendidikan harus mampu berorientasi dalam mengantisipasi perkembangan teknologi agar masyarakat tidak salah dalam menggunakannya.

Pengaruh modernisasi sangat mendorong perkembangan manusia yang berdampak pada masyarakat pada posisi masa lampau hingga sampai saat ini pada masa perkembangan teknologi. Perubahan-perubahan kehidupan masyarakat yang belum siap menerima akan perkembangan zaman mengakibatkan pendidikan masih bercermin pada kebiasan-kebiasaan budaya masyarakat dalam berbangsa dan bernegara. Maka adanya perkembangan teknologi sangat berdampak untuk meningkatkan pendidikan hingga meningkatkan pengetahuan masyarakat dan meningkatkan normanorma dalam bermasyarakat.

Pandangan manusia terhadap pendidikan hingga nilai budaya adanya pergeseran wawasan terhadap nilai-nilai budaya hingga keterampilan masyarakat lampau yang tidak mengenal perkembangan teknologi sampai dengan masyarakat yang telah mengenal perkembangan teknologi. The Liang Gie (1998: 44) mengatakan bahwa "any process, formal or in formal, that helps develop the potentialities ofhuman beings, including their knowledge, capabilities, behaviourpattems and values". Mengenai tulisan tersebut bahwasannya adanya tugas penditing terhadap pendidikan yaitu harus dapat mengembangkan sikap ilmiah, nilai serta kebiasaan-kebiasaan manusia dalam berpikir agar dapat memberi peran terhadap perkembangan zaman. Maka pemerintah harus berperan penting untuk meningkatkan pendidikan di Indonesia.

Pembelajaran atau pendidikan sangat berpengaruh terhadap pembentukan karakter manusia yang mampu berpikir secara relegius serta dapat berpikir secara ilmiah. Tetapi adanya permasalahan terhadap pendidikan untuk mendapatkan hasil yang baik. Adanya ketidakseimbangan pendidikan 
karena masyarakat menjalankan proses pendidikan hanya untuk mendapatkan pekerjaan. Karakter masyarakat tidak terbentuk dengan baik karena tidak ada fasilitas yang memadahi dalam proses pembelajaran. Pendidikan hanya mampu mencerdaskan masyarakat saja. Sesuai dengan undangundang RI No. 20 Tahun 2003 Pasal 1 mengenai "pengembangan kualitas karakteris siswa dalam nilai spiritual, relegius serta kedewasaan diri sendiri dalam memperlakukan masyarakat lainnya dalam berbangsa dan bernegara.

Berkembanganya teknologi dan informasi terhadap dunia pendidikan dapat menunjang proses pembelajaran berbasis e-learning dengan memanfaatkan fasilitas internet atau jaringan yang dapat menjalin komunikasi antara siswa yang satu dengan siswa yang lainnya beserta dengan guru-gurunya. Guru dan siswa juga dapat melihat atau mengecek nilai-nilai, jadwal pembelajarannya, hingga dapat mengirimkan tugas secara mudah kepada gurunya tanpa harus bertemu langsung.

Komunitas belajar bertujuan untuk mempersatukan kelompok orang agar mendapatkan tujuan yang akan dicapai secara bersama. Pandangan sosiologi terhadap kelompok yaitu orang-orang yang saling berkomunikasi hingga menjalin hubungan antara orang tersebut sehingga orang tersebut mendapatkan tujuan tertentu terhadap hasil komunikasi di dalam kelompok.

Terbentuknya sebuah kelompok karena adanya orang-orang yang saling berhubungan interaksi atau berkomunikasi dalam kesehariannya, melakukan diskusi hingga bercerita satu sama lainnya. Orang-orang tersebut merasakan apa yang mereka diskusikan baik di sekolah maupun diluar sekolah sehingga menemukan permasalahan yang dapat didiskusikan. Contoh sebuah jalinan antara orang tua, sesame rekan sejenis maupun rekan lawan jenisnya.

Membuat komunitas pembelajaran yaitu permulaan untuk melaksanakan sebuah penelitian ini. Terbentuknya komunitas karena adanya kepentingan terhadap orang-orang yang bersangkuta. Penelitian ini di dukung oleh para guru dan kepala sekolah sehingga tingkah laku orang tua dalam mendapingi anaknya dalam proses pembelajaran dapat diketahui permasalahannya dalam penerapan komunitas pembelajaran. Mengamati penggunaan sosial media untuk proses pembelajaran dalam sebuah komunitas pembelajaran yang bersifat formal. Peneliti mengharapkan yaitu; 1) Akan membentuk sebuah komunitas pembelajaran berasaskan sosial media, 2) Penelitian ini diharapkan terpublikasi secara ilmiah tingkat nasional maupun tingkat internasional untuk mendapatkan hasil yang lebih baik dalam menyempurnakan penelitian ini.

Pengguna ponsel pintar pada Negara Indonesia mengalami peningkatan. Berdasarkan salah satu lembaga penelitian menyatakan negara Indonesia berada pada posisi kelima untuk penggunaan smartphone dari berbagai negara. Pengguna smartphone terbesar yaitu China sebanyak 1 milliar lebih manusia, negara Tirai Bambu, berjumlah 422 juta lebih rendah dari China, negara Amerika Serikat mempunyai 188 juta penduduk. Posisi ketiga hingga seterusnya ditempati pada India, Brazil dan Jepang. Dari hasil riset tersebut negara Indonesia dinyatakan berada pada posisi ke 5 dengan angka 47 penduduk yang aktif dalam menggunakan smartphone dengan presentase kurang lebih 14\%. (Anonim. 2014. www. inet.detik.com diakses 24 februari 2017).

Menggunakan smartphone telah jadi bagian dari kebutuhan masyarakat apalagi dikalangan anak remaja pada saat ini. Smartphone dijadikan sebagai alat komunikasi, media informasi hingga untuk bermain game pada para siswa, sehingga memberikan dampak positif menurut para siswa yang telah terbiasa menggunakan smartphone. Sebagai contoh nilai positif yang didapatkan oleh siswa yaitu dapat membantu dan memudahkan para siswa belajar secara daring baik di lingkungan sekolah maupun di lingkungan luar sekolah, dapat berkomunikasi dengan muda kepada orang tua, keluarga hingga teman sejawatnya. Nilai negatif juga memberikan dampak kepada kesehatan siswa yaitu mata bisa saja mengalami penurunan kesehatan karena adanya radiasi yang dipancarkan oleh smartphone tersebut, 
banyaknya informasi-informasi negatif seperti film porno yang mudah diakses dan bisa saja minat belajar siswa menurun karena adanya daya tarik media sosial hingga permainan game di dalam smartphone tersebut.

Berdasarkan gambaran peneliti WhatsApp (WA) memudahkan dalam penggunaannya terhadap masyarakat karena banyak fitur hiburan seperi gambar-gambar animasi di dalamnya serta dapat mengirim pesan suara, mengirim video serta dapat mengirim lokasi keberadaan pengguna dimanapun mereka berada. Adanya perkembangan teknologi akan membantu masyarakat dalam mendapatkan informasi dengan cepat sehingga bisa membiasakan diri dalam meningkatkan proses komunikasi antara masyarakat.

Kelebihan whatsapp bila disandingkan bersama aplikasi pada umumnya sangat berbeda, whatsapp sangat mudah dalam proses pengiriman berupa pesan yang ditunjang dengan berbagai animasi, gambar, ataupun dapat mengiri foto, video hingga suara secara langsung. Berbeda dengan aplikasi Line dan aplikasi Blackberry. Aplikasi Whatsapp juga memiliki kelebihan fasilitas seperti GPS yang dapat menentukan letak posisi pengguna dimanapun mereka berada serta dalam menggunakannya kita tidak perlu memasukkan sandi disetiap harus membuka aplikasi tersebut.

Kenyataan saat ini terhadap siswa menggambarkan bahwasannya penggunaan smartphone hanyak digunakan secara umum seperti menelpon, SMS dan chatting. Perkembangan teknologi tidak di manfaatkan dengan baik dalam proses pembelajaran guna meningkatkan mutu pendidikan. Evrin Baran (2014) mengemukakan, smartphone salah satu media belajar yang dapat dikembangkan dalam proses pembelajaran serta dapat menarik minat belajar siswa dalam meningkatkan kualiatas proses pembelajaran. Penelitian ini menunjukkan hasil yang signifikan dalam meningkatnya kualiats proses pembelajaran siswa sesudah diberikan pembelajaran berbasis mobile learning. Penggunaan mobile learning dapat digunakan juga untuk meningkatkan kesenangan diri untuk proses belajar mengajar serta dapat membantu guru dalam proses pembelajaran.

Setelah peneliti melakukan observasi awal pada tanggal 07 juni 2017 kepada siswa-siswi di SMA Muhammadiyah 1 Unismuh Makassar, penggunaan smartphone sudah menjadi kebutuhan pribadi setiap siswa dalam kesehariannya di sekolah maupun di luar sekolah. Sehingga aktivitas belajar siswa diluar jam belajar dan minat membaca siswa semakin menurun dikarenakan penggunaan smartphone yang mempunyai berbagai fitur, aplikasi WhatsApp, LINE, BBM sebagai sarana komunikasi dan sangat memudahkan para siswa dalam mendapatkan sumber informasi yang bersifat positif maupun negative.

Maka karena itu penggunaan aplikasi WhatsApp terhadap mata pelajaran sejarah dengan cara memberikan bekal belajar atau sumber belajar terhadap siswa sebelum melakukan proses pembelajaran yang akan berlangsung untuk memudahkan pemahaman siswa terhadap materi belajar melalui pembentukan sebuah komunitas belajar siswa yang bertujuan untuk meningkatkan aktivitas pembelajaran formal serta pembelajaran nonformal.

Mengenai penjelasan tersebut, peneliti akan melaksanakan sebuah penelitian yang akan membahas persoalan penerapan WhatsApp sebagai sebuah komunitas belajar siswa dengan judul "Penerapan Komunitas Belajar Melalui Aplikasi WhatsAppSebagai Upaya Meningkatkan Aktivitas Belajar Sejarah".

\section{METODE}

Penulis pada penelitian ini menggunakan jenis Penelitian Tindak Kelas (PTK). Di mana riset penelitian ini membahas tentang program dan pengalaman orang dilingkungan objek penelitian. Penulis menggunakan metode menganalisis permasalahan pada penelitian ini yaitu metode kualitatif deskriptif dengan pembahasan menyangkut penerapan komunitas belajar melalui aplikasi Whatsaap 
sebagai upaya peningkatan aktivitas belajar sejarah pada siswa kelas X di SMA Muhammadiyah 1 Unismuh Makassar. Metode yang digunakan memberikan penjelasan secara detail menyangkut datadata dalam penelitian sebagai objek dan memberikan gambaran serta memaparkan kejadian-kejadian yang telah terjadi.

Penelitian tersebut berupaya menjawab dan menjelaskan atas rumusan permasalahan yaitu, Bagaimana penerapan Komunitas Belajar Siswa Melalui Aplikasi Whatsapp Messenger Sebagai Upaya Efesiensi Pembelajaran Sejarah Siswa Kelas X di SMA Muhammadiyah 1 Unismuh Makassar. Untuk mengkaji hal tersebut maka snowball sampling yang akan digunakan oleh peneliti sebagai tipe penelitian.

Lokasi penelitian yaitu di SMA Muhammadiyah 1 Unismuh Makassar. Di mana lokasi tersebut berada di tengah-tengah kota yang ramai akan penduduk serta peneliti mudah dalam menjangkau pada saat ingin melakukan proses penelitian karena sekolah tersebut juga berada di dalam kampus Uiniversitas Muhammadiyah Makassar tempat peneliti menjalankan studi. Siswa-siswa SMA Muhammadiyah 1 Unismuh Makassar sudah mulai menggunakan smartphone berbasis android maupun IOS sehingga membantu peneliti lebih mudah dalam menyelesaikan penelitian.

Sumber data dalam penelitian ini sangat memperhatikan data-data yang akan digunakan karena data tersebut sangat membantu dalam proses penelitan serta menjadi tolak ukur dalam proses penelitian dan sebagai sumber informasi yang akan digunakan. Peneliti mengelompokkan menjadi dua data yaitu sumber data skunder dan sumber data primer:

Sumber data primer bagian data yang secara langsung didapatkan dari sampel dengan menggunakan cara wawancara/interview diantaranya oleh guru sejarah serta para siswa/murid yang bersangkutan. Sumber data skunder yaitu, bersumber dari berbagai informasi seperti media atau berkasberkas yang berada di sekolah diantaranya, arsip/file, dekomuntasi, absensi, nilai-nilai siswa, kepustakaan, jurnal, dan karya tulis ilmiah yang dapat menunjang dalam proses penelitian.

Prosedur Penelitian, pada bagian ini akan menggambarkan kerangka operasional tentang pelaksanaan proses meneliti: a) Awal siklus: 1) Planning (membuat RPP, dan lembar observasi aktivitas siswa), 2) Action (melaksanakan proses belajar mengajar berdasarkan RPP serta melakukan observasi terhadap keterlaksanaan RPP dan aktivitas siswa), 3) Observasi (menganalisis aktivitas belajar), 3) Refleksi (observasi terdahap keterlaksanaan RPP dan Aktivitas belajar siswa). a) Siklus II: 1) Perencanaan tindakan/planning berdasarkan siklus I (membuat RPP, dan lembar observasi aktivitas siswa), 2) Action (melaksanakan proses belajar mengajar berdasarkan RPP serta melakukan observasi terhadap keterlaksanaan RPP dan aktivitas siswa setelah penerapan komunitas belajar melalui aplikasi whatsapp), 3) Observasi (menganalisis aktivitas belajar), 4) Refleksi (observasi terdahap keterlaksanaan RPP dan Aktivitas belajar siswa).

Pada penelitian ini penulis mengambil 23 sampel diantaranya 22 siswa dan 1 guru mata pelajaran sejarah dari seluruh jumlah siswa sebagai populasi yang memliki karakter dan kualitas yang baik untuk dijadikan sebagai subjek penelitian di SMA Muhammadiyah 1 Unismuh Makassar.

Tabel 1. Sampel Subjek Penelitian

\begin{tabular}{|c|c|c|c|c|}
\hline \multirow[t]{2}{*}{ No. } & \multirow[t]{2}{*}{ Kelas } & \multicolumn{2}{|c|}{ Jenis Kelamin } & \multirow[t]{2}{*}{ Jumlah } \\
\hline & & Laki-laki & Perempuan & \\
\hline 1. & & 9 Siswa & 13 Siswa & 22 Siswa \\
\hline \multicolumn{4}{|c|}{ Jumlah } & 22 Siswa \\
\hline
\end{tabular}


Dalam proses pengambilan sampel peneliti sangat memperhatikan karakteristik siswa agar dapat memperoleh data yang maksimal dan baik serta dapat berfungsi sebagai subjek penelitian untuk mendapatkan hasil sesuai dengan permasalahan di lokasi penelitian. Peneliti juga mempunyai cara dalam menetukan sampel yaitu dengan cara simple random sampling. Cara atau teknik ini dilakukan secara random/acak tidak memperhatikan karakteristik pada siswa.

Proses penelitian harus memperhatikan cara pengumpulan data sehingga tidak ada kekeliruan disaat proses penelitian berjalan. Hal pertama yang harus diperhatikan yaitu tekniknya dalam mengumpulkan data seperti memperhatikan berbagai sumber dan berbagai cara dalam proses penelitian. Pengumpulan data dilakukan yaitu: 1) Wawancara Mendalam yaitu, melakukan proses tanya jawab kepada para siswa dan guru yang menjadi bagian dari sampel/subjek penelitian agar mendapatkan gambaran hasil dalam proses penelitian. 2) Observasi aktivitas siswa yaitu, memperhatikan tingkah laku atau aktivitas siswa dalam proses pembelajaran di kelas maupun diluar kelas secara sistematis dan terus-menerus selama proses penelitian berlangsung. Sehingga mendapatkan hasil aktivitas siswa yang baik. 3) Dokumentasi yaitu, mengumpulkan arsip-arsip atau data yang menyangkut perkembangan aktivitas siswa serta surat-surat yang menunjang dalam proses penelitian dan dokumentasi berupa foto-foto aktivitas siswa.

Penelitian kualitatif dalam proses penelitian merupakan analisis data yang perlu diperhatikan karena sangat penting dalam menentukan hasil peneliti baik secara sistematis, komprehensif dan komunikatif dalam menentukan hasil sehingga perlu merangkai dan merespon data serta merumuskan secara logis. Peneliti menggunakan model analisis interaktif (Interactive Model Analisys). Proses penelitian mempunyai tiga unsur tujuan yaitu: 1) Reduksi Data yaitu, menyeleksi data fokus terhadap data, menulis dengan baik. Proses ini dilakukan dari sebelum peneliti turun lokasi penelitian hingga sampai proses penelitian selesai. 2) Penyajian data yaitu, merumuskan dengan baik dari hasil-hasil data yang telah ditemukan di lokasi penelitian sehingga data jelas dan benar, sehingga tidak ada kekeliruan di dalam penyajian data. 3) Penarikan kesimpulan yaitu, hasil dari pengumpulan data dari berbagai sumber sehingga dapat menarik kesimpulan atau reduksi data. Peneliti menggambarkan skema yang dapat dilihat:

\section{Gambar 1. Model Analisis Interaktif}

\section{Skema Model Analisis Interaktif}

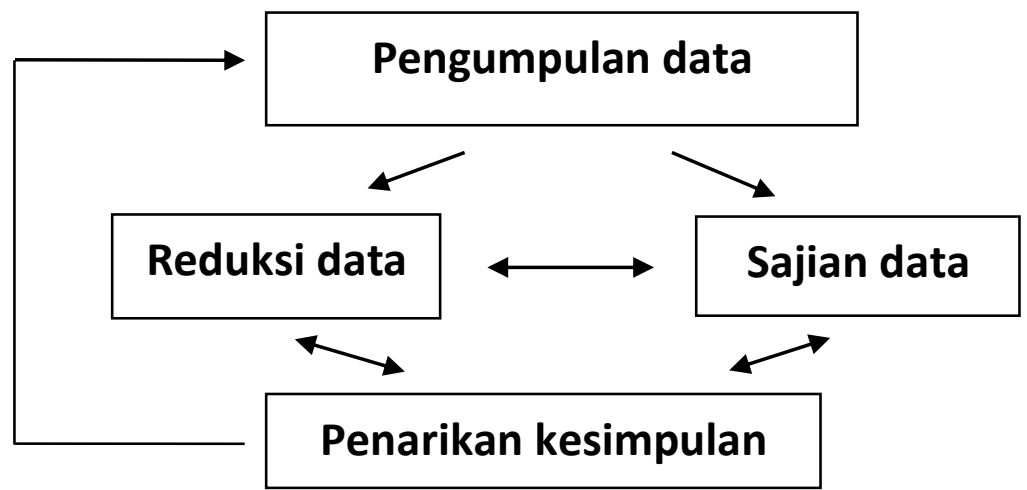

Skema diatas, menggambarkan proses pengumpulan data secara reduksi data sehingga semua data yang telah terrkumpul memberikan hasil yang baik dalam proses penelitian dan data dapat di kembangkan secara baik. Data-data yang telah terkumpul akan di rangkum untuk menghasilkan kesimpulan berdasarkan hasil pengumpulan selama proses penelitian. 
Data merupakan yang wajib untuk dilakukan validasi, maka dalam proses penelitian ini validasi data sangatlah penting untuk mengukur keabsahan data yang akan didapatkan dari lokasi peneltian agar dapat dipertanggung jawabkan. Peneliti melakukan metode trigulasi agar dapat menemukan kebenaran dari data-data penelitian yaitu; 1) Sumber, memperhatikan ulang data-data yang telah didapatkan dari berbagai informan. 2) Metode triangulasi dilakukan peneliti untuk melakukan pendekatan multimode agar keabsahan data dapat dipertanggung jawabkan kebenarannya. 3) Teori trianggulasi dianggap nyata dan tidak bisa diperiksa.

\section{HASIL DAN PEMBAHASAN}

Peneliti memperoleh hasil dan pembahasan dari pemantauan penerapan komunitas belajar melalui aplikasi whatsapp sebagai upaya meningkatkan aktivitas belajar sejarah terhadap sampel peneltian. Peneliti mendapatkan data melalui guru dan siswa dengan menggunakan teknik wawancara serta observasi aktivitas belajar siswa melalui aplikasi whatsapp serta observasi aktivitas belajar siswa secara langsung di kelas.

\section{HASIL}

Tabel 2. Aktivitas Belajar Siswa Melalui Aplikasi WhatsApp

\begin{tabular}{clcc}
\hline No. & \multicolumn{1}{c}{ Aspek yang di amati } & $\begin{array}{c}\text { Jumlah } \\
\text { Siswa }\end{array}$ & $\begin{array}{c}\text { Persen } \\
(\%)\end{array}$ \\
\hline 1 & Siswa yang mengakses grup whatsapp & 15 & 68.18 \\
\hline 2 & $\begin{array}{l}\text { Siswa yang memperhatikan/membaca pesan diskusi grub } \\
\text { whatsapp }\end{array}$ & 22 & 100 \\
\hline 3 & Siswa yang aktif dalam diskusi grupwhatsapp & 5 & 22.72 \\
\hline 4 & $\begin{array}{l}\text { Siswa yang bertanya jika tidak mengerti terhadap materi } \\
\text { diskusi grup whatsapp }\end{array}$ & 4 & 18.18 \\
\hline 5 & Siswa yang menanggapi materi diskusi grup whatsapp & 3 & 13.63
\end{tabular}

Hasil dari tersebut adalah pengamatan langsung aktivitas dalam siswa melakukan proses pembelajaran melalui komunitas belajar mandiri di dalam grup whatsapp, sesuai dengan poin pertama yang telah diamati tentang siswa berjumlah 15 yang mengakses grup whatsapp sebesar $68.18 \%$, poin kedua siswa berjumlah 22 yang memperhatikan/membaca pesan diskusi grub whatsapp sebesar 100\%, poin ketiga siswa berjumlah 5 yang aktif dalam diskusi grup whatsapp sebesar $22.72 \%$, poin keempat siswa berjumlah 3 yang bertanya jika tidak mengerti terhadap materi diskusi grup whatsapp sebesar $18.18 \%$ dan poin kelima siswa yang menanggapi materi diskusi grup whatsapp sebesar 13.63\%, dengan rata-rata persentase aktivitas siswa adalah 68.18\%. Di mana siswa yang tergabung di dalam grup whatsapp berjumlah 15 murid dari 22 jumlah murid keseluruhan kelas X. 
Tabel 3. Aktivitas Belajar Siswa Sebelum Penerapan Komunitas WhatsApp

\begin{tabular}{|c|c|c|c|c|c|}
\hline \multirow[t]{2}{*}{ No. } & \multirow[t]{2}{*}{ Aktivitas Siswa } & \multicolumn{3}{|c|}{ Siklus 1} & \multirow{2}{*}{$\begin{array}{c}\text { Persen } \\
\%\end{array}$} \\
\hline & & 1 & 2 & 3 & \\
\hline 1 & Siswa yang tidak terlambat & 20 & 22 & 21 & 95.45 \\
\hline 2 & $\begin{array}{lll}\text { Siswa yang } & \text { memperhatikan/menanggapi } \\
\text { apersepsi/motivasi } & \end{array}$ & 4 & 3 & 6 & 19.69 \\
\hline 3 & $\begin{array}{l}\text { Siswa memperhatikan guru saat proses } \\
\text { pembelajaran }\end{array}$ & 18 & 18 & 20 & 84.84 \\
\hline 4 & Siswa yang aktif memperhatikan diskusi & 10 & 13 & 12 & 53.03 \\
\hline 5 & Siswa yang aktif dalam diskusi kelas & 4 & 4 & 6 & 21.21 \\
\hline 6 & Siswa yang bertanya jika tidak mengarti & 4 & 5 & 8 & 25.75 \\
\hline 7 & $\begin{array}{l}\text { Siswa yang mengumpulkan informasi/data terkait } \\
\text { dengan pertanyaan yang tidak dimengerti }\end{array}$ & 11 & 14 & 12 & 56.06 \\
\hline 8 & $\begin{array}{l}\text { Siswa menganalisis informaasi/data terkait dengan } \\
\text { pertanyaan yang tidak dimengerti }\end{array}$ & 8 & 8 & 9 & 37.87 \\
\hline 9 & $\begin{array}{l}\text { Siswa yang melakukan refleksi/evaluasi } \\
\text { terhadap proses pembelajar } \\
\text { an yang berlangsung }\end{array}$ & 2 & 2 & 2 & 9.09 \\
\hline 10 & $\begin{array}{l}\text { Siswa yang memperhatikan penugasan/tindak } \\
\text { lanjut dari materi hari ini }\end{array}$ & 15 & 20 & 20 & 83.33 \\
\hline & Total & & & & 48.632 \\
\hline
\end{tabular}

Hasil dari tabel tersebut adalah gambaran pengamatan dalam proses aktivitas siswa di dalam proses pembelajaran sebelum penerapan komunitas belajar melalui aplikasi whatsapp, sesuai pada poin pertama yang telah diamati tentang siswa yang tidak terlambat sebesar $95.45 \%$ berjumlah 22 siswa, poin kedua siswa yang memperhatikan/menanggapi apersepsi/motivasi sebesar $19.69 \%$ berjumlah 6 siswa, poin ketiga Siswa memperhatikan guru saat proses pembelajaran sebesar $84.84 \%$ berjumlah 20 siswa, poin keempat siswa yang aktif memperhatikan diskusi sebesar $53.03 \%$ berjumlah 13 siswa, poin kelima siswa yang aktif dalam diskusi kelas sebesar $21.21 \%$ berjumlah 6 siswa, poin keenam siswa yang bertanya jika tidak mengerti sebesar $25.75 \%$ berjumlah 8 siswa, poin ketujuh siswa yang mengumpulkan informasi/data terkait dengan pertanyaan yang tidak dimengerti sebesar $56.06 \%$ berjumlah 14 siswa, poin kedelapan siswa menganalisis informaasi/data terkait dengan pertanyaan yang tidak dimengerti sebesar $37.87 \%$ berjumlah 9 siswa, poin kesembilan siswa yang melakukan refleksi/evaluasi terhadap proses pembelajaran yang berlangsung sebesar $9.09 \%$ berjumlah 2 siswa, 
poin kesepuluh siswa yang memperhatikan penugasan/tindak lanjut dari materi hari ini sebesar $83.33 \%$ berjumlah 20 siswa, dengan total persentase aktivitas siswa adalah $48.632 \%$.

Tabel 4. Aktivitas Belajar Siswa Setelah Penerapan Komunitas WhatsApp

\begin{tabular}{|c|c|c|c|c|c|}
\hline No. & Aktivitas Siswa & & klus & & Persen \\
\hline & & 1 & 2 & 3 & $\%$ \\
\hline 1 & Siswa yang tidak terlambat & 22 & 21 & 22 & 98.48 \\
\hline 2 & $\begin{array}{l}\text { Siswa yang memperhatikan/menanggapi } \\
\text { apersepsi/motivasi }\end{array}$ & 5 & 9 & 7 & 31.81 \\
\hline 3 & $\begin{array}{l}\text { Siswa memperhatikan guru saat proses } \\
\text { pembelajaran }\end{array}$ & 20 & 22 & 19 & 92.42 \\
\hline 4 & Siswa yang aktif memperhatikan diskusi & 12 & 15 & 16 & 65.15 \\
\hline 5 & Siswa yang aktif dalam diskusi kelas & 8 & 10 & 10 & 42.42 \\
\hline 6 & Siswa yang bertanya jika tidak mengarti & 6 & 5 & 6 & 25.75 \\
\hline 7 & $\begin{array}{l}\text { Siswa yang mengumpulkan informasi/data } \\
\text { terkait dengan pertanyaan yang tidak } \\
\text { dimengerti }\end{array}$ & 11 & 12 & 15 & 57.57 \\
\hline 8 & $\begin{array}{l}\text { Siswa menganalisis informaasi/data terkait } \\
\text { dengan pertanyaan yang tidak dimengerti }\end{array}$ & 8 & 8 & 9 & 37.87 \\
\hline 9 & $\begin{array}{l}\text { Siswa yang melakukan refleksi/evaluasi } \\
\text { terhadap proses pembelajaran yang } \\
\text { berlangsung }\end{array}$ & 2 & 3 & 5 & 15.15 \\
\hline 10 & $\begin{array}{l}\text { Siswa yang memperhatikan penugasan/tindak } \\
\text { lanjut dari materi hari ini }\end{array}$ & 17 & 20 & 20 & 86.36 \\
\hline
\end{tabular}

Berdasarkan tabel di atas adalah hasil pengamatan observasi aktivitas siswa di dalam proses pembelajaran setelah penerapan komunitas belajar melalui aplikasi whatsapp, sesuai pada poin pertama yang telah diamati tentang Siswa yang tidak terlambat sebesar $98.48 \%$ berjumlah 22 siswa, poin kedua siswa yang memperhatikan/menanggapi apersepsi/motivasi sebesar $31.81 \%$ berjumlah 9 siswa, poin ketiga Siswa memperhatikan guru saat proses pembelajaran sebesar $92.42 \%$ berjumlah 22 siswa, poin keempat siswa yang aktif memperhatikan diskusi sebesar $65.15 \%$ berjumlah 16 siswa, poin kelima siswa yang aktif dalam diskusi kelas sebesar $42.42 \%$ berjumlah 10 siswa, poin keenam siswa yang bertanya jika tidak mengerti sebesar $25.75 \%$ berjumlah 6 , poin ketujuh siswa yang mengumpulkan informasi/data terkait dengan pertanyaan yang tidak dimengerti sebesar $57.57 \%$ berjumlah 15 siswa, poin kedelapan siswa menganalisis informaasi/data terkait dengan pertanyaan yang tidak dimengerti sebesar $37.87 \%$ berjumlah 9 siswa, poin kesembilan siswa yang melakukan refleksi/evaluasi terhadap 
proses pembelajaran yang berlangsung sebesar $15.15 \%$ berjumlah 5 siswa, poin kesepuluh siswa yang memperhatikan penugasan/tindak lanjut dari materi hari ini sebesar $86.36 \%$ berjumlah 20 siswa, dengan total persentase aktivitas siswa adalah $55.298 \%$.

\section{Pembahasan}

Gambaran Umum Siswa Kelas X SMA Muhammadiyah 1 Unismuh Makassar sebagai sampel proses penelitain ini adalah siswa kelas X yaitu 22 siswa (9 laki-laki dan 13 perempuan). Penerapan komunitas belajar melalui aplikasi whatsapp kepada siswa di mata pelajaran sejarah pada kelas ini dilaksanakan di luar proses jam belajar mengajar berlangsung. Guru sejarah berpendapat, media $e$ learning yaitu aplikasi whatsapp sangat baik untuk digunakan dalam proses pembelajaran di dalam kelas maupun diluar kelas karena siswa sudah bisa menggunakan sosial media dan sudah menjadi kebutuhan siswa dalam menggunakan smartphone baik di sekolah maupun di rumahnya.

Peneliti melakukan perencanaan yaitu; melakukan observasi aktivitas siswa, penyiapan paket data internet, arahan cara mendownload aplikasi whatsapp dan membuat grup komunitas belajar. Cooperative learning diteraokan dalam proses belajar mengajar mengikuti ketentuan kurikulum 2013. Di mana siswa diharapkan berperan aktif dalam proses pembelajaran berlangsung saat guru sedang mengajar. Proses belajar nonformal ini ditunjang oleh aplikasi whatsapp sehingga mempermudah guru dan siswa dalam proses pembelajaran baik di kelas maupun diluar kelas. Proses sosialisasi juga digunakan pada awal pertemuan mengenai penerapan aplikasi whatsapp kepada siswa kelas X SMA Muhammadiyah 1 Unismuh Makassar. Data penelitian ini didapatkan saat melakukan proses wawancara mendalam terhadap sampel atau subjek peneltian yaitu guru dan siswa.

Pada tahap pelaksaan dan observasi dilaksanakan peneliti melakukan pertemuan dengan guru yang bersangkutan dan meminta arahan dalam melakukan penelitian dengan hasil guru mengarahkan peneliti untuk melakukan penerapan aplikasi whatsapp, pemberian arahan, informasi menyangkut materi mata pelajaran sejarah dan motivasi belajar kepada siswa sebelum melakukan proses pembelajaran.

Pelaksanaan dengan penerapan komunitas belajar melalu aplikasi whatsapp. Tujuan penggunaan aplikasi whatsapp ini pada saat diluar jam proses belajar mengajar yaitu guna meningkatkan aktivitas siswa agar mudah memberikan argument dalam proses pembelajaran di luar kelas maupun di luar sekolah. Peneliti mengadakan diskusi dalam aplikasi whatsapp untuk mengemukakan materi sejarah yang akan dipelajari sebelum memasuki kelas dan menstimulus siswa dalam meningkatkan aktivitas berpendapat dan berdiskusi. Materi pembelajaran akan diberikan sesuai apa yang akan diberikan oleh guru tersebut.

Refleksi dilakukan dari proses pemantauan. Peneliti dengan guru memperhatikan observasi aktivitas belajar, memperhatikan permasalahan aktivitas belajar terhadap siswa kelas X di SMA Muhammadiyah 1 Unismuh Makassar. Berdasarkan data dari observasi aktivitas pembelajaran, perbaikan aktivitas belajar terhadap siklus II memberikan hasil yang baik, sebanyak 22 siswa telah ikut berpartisipasi saat belajar, menghasilkan aktivitas pembelajaran meningkat mencapai persentase yang diharapkan, yaitu 55.298\%.

Keberhasilan peningkatan aktivitas belajar pada siklus II tidak lepas dari penerapan komunitas belajar melalui aplikasi whatsapp yang memudahkan siswa dalam berdiskusi, menyelesaikan tugastugas dan mengerjakan soal bersama tanpa harus bertatap muka. Penerapan komunitas belajar melalui aplikasi whatsapp telah berhasil meningkatkan partisipasi dalam proses belajar kelompok, sehingga aktivitas pembelajaran dapat meningkat. Peneliti bersama dengan guru melakukan pengamatan 
terhadap penerapan komunitas belajar melalui aplikasi whatsapp dapat dinyatakan telah meningkatkan aktivitas belajar siswa dan penelitian dihentikan saat siklus II.

Wawancara dengan guru sejarahnya menghasilkan pembahasan yaitu, aplikasi whatsapp sangat baik digunakan dalam proses pembelajaran sebagaimana siswa telah sering menggunakan smartphone dan sudah menjadi kebutuhan siswa dalam menggunakan smartphone baik di sekolah maupun dirumahnya. Sehingga penggunaan smartphone yang dimiliki siswa tidak disalah gunakan yang dapat merusak karakteristik dan pola pikir siswa karena tidak bisa dipungkiri kecanggihan teknologi sudah sangat modern di mana segala informasi baik buruknya dapat di akses secara mudah melalui internet dan dari beberapa aplikasi-aplikasi sosial media. Dengan adanya komunitas belajar melalui aplikasi whatsapp aktivitas belajar siswa dapat meningkat maupun kelas formal ataupun nonformal.

Wawancara dengan siswa menghasilkan informasi dari siswa kelas X SMA Muhammadiyah 1 Unismuh Makassar, penerapan komunitas pembelajaran melalui aplikasi whatsapp sangat baik bagi siswa dalam proses pembelajaran karena dapat mengemukakan pendapat dengan mudah ketika melakukan diskusi, memecahkan masalah yang tidak diketahui menyangkut materi sejarah dan dapat memudahkan siswa dalam proses pembelajaran ketika guru memberikan tugasyang diberikan oleh guru bersama dimanapun mereka berada tanpa harus bertemu secara langsung disuatu tempat. Sehingga siswa merasa termudahkan dalam mencari informasi menyangkut materi pembelajaran dan memudahkan siswa untuk mengerjakan soal-soal yang telah diberikan. Berdasarkan satu paradigma baru penerapan komunitas belajar melalui aplikasi whatsapp ternyata ada kemudahan dan dampak baik terhadap berbagai element manusia serta untuk siswa. Berdasarkan penilaian tersebut menunjukan tanggapan yang bagus terhadap siswa. Siswa berpendapat yaitu, penerapan komunitas belajar melalui aplikasi whatsapp mempunyai peran baik dalam proses belajar mengajar. Tetapi belum terlirik oleh pihak sekolah dan pihak pendidikan tidak mengetahui bagaimana itu penerapan komunitas belajar melalui aplikasi whatsapp, maka perlunya dilakukan sosialisasi. Peneliti mendapatkan hasil ternyata penilaian aktivitas belajar siswa melalui penerapan komunitas aplikasi whatsapp memerlukan kesiapan yang baik.

Berdasarkan kajian (Khairi, 2013) mengemukakan proses pengamatan guru terhadap siklus I terbilang "Sangat Baik", hasil 65,63\% dengan penilaian 56- 75\%, serta siklus II terjadi peningkatan $85,94 \%$ terbilang "Baik" dengan penilaian 76-100\% . pengapatan siswa terhadap siklus I adalah $66,88 \%$ atau terbilang "Sangat Baik", 66,88\% dengan penilaian $56-75 \%$ serta siklus II hasil pengamatan siswa terjadi peningkatan $85,00 \%$ terbilang "Baik", karena $85,00 \%$ dengan penilian $76-$ $100 \%$. Peningkatan aktivitas guru dan siswa dapat mempengaruhi dalam proses pemblajaran. Awal observasi mendapatkanpresentase $45,00 \%$ yaitu berjumlah 9 siswa, terhadap siklus I terjadi peningkatan yaitu 13 siswa dengan presentase $65,00 \%$, terhadap siklus II peningkatan 17 orang siswa yaitu hasil dari presentase $85,00 \%$. Penerapan strategi komunitas belajar meningkat pada siswa kelas 24-8 serta peningkatan proses pembelajaran siswa terhadap mata pelajaran Sains di Kelas V Sekolah Dasar Negeri 019 Muara Uwai Kecamatan Bangkinang Seberang Kabupaten Kampar.

Jadi dapat ditarik kesimpulan bahwa penerapan komunitas melalui aplikasi whatsapp dapat meningkatkan aktivitas pembelajaran siswa kelas $X$ pada mata pelajaran sejarah di SMA Muhammadiyah 1 Unismuh Makassar, menghasilkan peningkatan aktivitas proses pembelajaran terlihat dari hasil proses wawancara mendalam terhadap guru beserta siswa, persentasi antara Siklus I dan Siklus II dapat menunjang hasil dari penelitian ini. 


\section{KESIMPULAN DAN SARAN}

Berdasarkan hasil penelitian tersebut peneliti menyimpulkan yaitu: 1) Secara umum penulis menyimpulkan bahwa pelaksanaan dan penerapan komunitas belajar melalui penggunaan aplikasi whatsapp ini pada saat di luar jam proses belajar mengajar secara langsung bertujuan agar dapat meningkatkan aktivitas siswa dalam proses pembelajaran di luar kelas maupun di luar sekolah. Peneliti mengadakan diskusi dalam aplikasi whatsapp untuk mengemukakan materi sejarah yang akan dipelajari sebelum memasuki kelas dan menstimulus siswa dalam meningkatkan aktivitas berpendapat dan berdiskusi. Materi-materi pembelajaran diberikan oleh guru sesuai dengan materi yang akan diajarkan dalam kelas. 2) Hasil pengamatan serta pembahasan terhadap pelaksanaan pada siswa kelas $\mathrm{X}$ SMA Muhammadiyah 1 Unismuh Makassar dapat dideskripsikan bahwa penerapan komunitas belajar melalui aplikasi whatsapp bisa memberikan peningkatan proses pembelajaran siswa berdasarkan hasil wawancara terhadap guru dan siswa, berdasarkan siklus I dan siklus II menunjang hasil penelitian. Aktivitas siswa terhadap penggunaan smartphone tidak mengalami kenaikan aktivitas dan tidak menutup kemungkinan minat belajar siswa cenderung menurun akibat siswa secara mudah mengakses internet dapat menikmati aplikasi-aplikasi sosial media yang dapat merusak karakter dan minat belajar siswa di luar jam belajar maupun dirumah yang membuat siswa menghiraukan tugas-tugas sekolah yang telah diberikan oleh gurunya. Maka orang tua siswa harus berperan penting terhadap penggunaan smartphone.

Berdasarkan hasil dari penelitian ini peneliti memberikan berbagai saran untuk para peneliti berikutnya yaitu: 1) Sebagai peneliti berikutnya dapat melakukan berbagai macam kajian dari berbagai data sumber serta memperbanyak referensi sesuai dengan penelitian ini. Agar mendapatkan hasil yang lebih akurat dan lengkap. 2) sebagai Peneliti berikutnya dapat memperhatikan kesiapan mental untuk melakukan penelitian agar hasil penelitian memberikan hasil yang maksimal serta dapat memperhatikan berbagai data sumber yang akurat untuk penelitian selanjutnya.

\section{DAFTAR PUSTAKA}

Anonim. (2014). Indonesia Masuk 5 Besar Negara Pengguna Smartphone. (online). Di akses https://inet.detik.com/consumer/d-2485920/indonesia-masuk-5-besar-negara-penggunasmartphone. pada tanggal 24 februari 2017 pukul 21:15 WITA.

Agustina, Penerapan Strategi Pembelajaran Aktif Tipe Komunitas Pembelajaran Kelas 2-4-8 untuk Meningkatkan Hasil Belajar IPS Ekonomi pada Siswa Kelas X SMAN 1 Batu Bersurat Kecamatan XIII Koto Kampar, Pekanbaru: Skripsi Pustaka UIN Suska Riau, 2011.

Baran, E. (2014). A Review of Research on Mobile Learning in Teacher Education. Educational Technology \& Society, 17(4), 17-32..

Depdiknas. 2003. Undang-undang RI No.20 tahun 2003.tentang sistem pendidikan nasional. Gie,The Liang .1998. Ensiklopedia Administrasi. Jakarta: Gunung Agung.

Melda Yanti, Penerapan Strategi Pembelajaran Aktif Tipe Komunitas Pembelajaran Kelas 2-4-8 untuk Meningkatkan Hasil Belajar PKn Siswa Kelas IV SDN 003 Siabu Kecamatan Salo Kabupaten Kampar Tahun Pelajaran 2011/2012, Pekanbaru: Skripsi Pustaka UNRI, 2011.

Mifta Khairi. (2013). Penerapan Strategi Pembelajaran Aktif Tipe Komunitas Pembelajaran Kelas 2-48 Untuk Meningkatkan Hasil Belajar Siswa Pada Mata Pelajaran Sains Di Kelas V Sekolah Dasar Negeri 019 Muara Uwai Kecamatan Bangkinang Seberang Kabupaten Kampar. Skripsi. 
TIW, Strategi untuk Meningkatkan Belajar Mengajar, (on line), Diselenggarakan oleh TIW (Teaching Improvement Workshop), Website: (http://www.uwlax.edu/catl/2012/03/22), 2012, diunduh Tgl 22 Desember 2013.

Yeni Kasmira, Peningkatan Hasil Belajar IPS melalui Penerpaan Strategi Pembelajaran Aktif Tipe Komunitas Pembelajaran Kelas 2-4-8 pada Siswa Kelas IVB SDN 002 Sipungguk Kecamatan Salo Kabupaten Kampar Tahun Pelajaran 2011/2012, Skripsi Pustaka UNRI, 2011. 